УДК 368.5

DOI: $10.15673 /$ fie.v12i1.1669

\author{
Танклевська Н.С. \\ доктор економічних наук, профресор \\ кафедра економіки та фінансів \\ E-mail: ntanklevska@gmail.com \\ ORCID ID:0000-0003-2906-4051 \\ Ярмоленко В.В. \\ аспірант \\ кафедра економіки та фінансів \\ Херсонський державний аграрний університет \\ вул. Стрітенська, 23, м. Херсон, Україна, 73006 \\ E-mail: vitalina.yarmolenko2016@gmail.com \\ ORCID ID:0000-0001-7567-0082
}

\title{
ПЕРСПЕКТИВИ АДАПТАЦІЇ ЗАРУБІЖНОГО ДОСВІДУ АГРОСТРАХУВАННЯ В УКРАЇНІ
}

В статті розглянуто зарубіжний досвід в галузі страхування ризиків аграрної сфери. Було досліджено системи страхування аграрних ризиків в різних країнах та їх характерні особливості. Вивчено історію розвитку страхування аграріїв та сучасних діючих учасників на ринку страхових послуг. Проаналізовано страхові системи Сполучених Штатів Америки та Канади. Також було систематизовано діючі моделі агрострахування. Висвітлено переваги та недоліки представлених світових моделей агрострахування. Доведено, що більшість країн світу роблять акцент на важливість страхування ризиків сільськогосподарського виробництва як незамінного фрінансово-економічного важеля розвитку сільського господарства та економіки країни. Проаналізувавши досвід страхування ризиків в сільському господарстві в зарубіжних країнах було виявлено, що на всіх досліджених ринках агрострахування уряд держав виступає партнером для страхових компаній та здійснює фінансові вливання, через субсидування страхових премій та у деяких випадках - покриває деяку частину страхових виплат. Було запропоновано застосування можливих ефективних напрямів страхування з державною фрінансовою підтримкою в сфрері сільського господарства у розрізі головних моделей ринку страхових послуг.

Ключові слова: ризик, агрострахування, системи агрострахування, моделі агрострахування, страхові продукти.

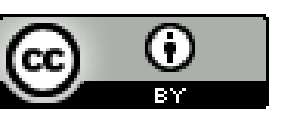

This work is licensed under a Creative Commons Attribution 4.0 International License http://creativecommons.org/licenses/by/4.0/
Постановка проблеми та її зв'язок з важливими науковими та практичними завданнями. Аграрне виробництво - ризикована галузь економіки. Аграрії стикаються з великою кількістю факторів, які можуть негативно вплинути на продукцію, яку вони виготовляють, як в рослинництва, так і в галузі тваринництва. Для зменшення або повного погашення фінансових втрат сільськогосподарських виробників застосовують страхування аграрних ризиків. На сьогодні в Україні механізм агрострахування є не достатньо розвиненим. Саме ефективне агрострахування дозволить сільському господарству вийти на новий рівень в економіці країни.

Нині постає проблема пошуку моделі та форми страхування, яка буде оптимально підходити для умов України. Незважаючи на стрімкий розвиток сектору сільського господарства в економіці України, рівень поширення страхування аграріїв у сільському господарстві становить 2-3\%.

Аналіз останніх публікацій по проблемі. Різні аспекти дослідження розвитку ринку страхових послуг в галузі сільського господарства висвітлено в працях таких вітчизняних вчених, як М. Александрова [5], О. Гудзь, П. Лайко, О. Лобова, Г. Минкіна [3], С. Навроцький, О. Панченко [6], О. Прокопчук [8], Н. Танклевська $[11,13]$, І. Федорович [9] та інші. Також даною проблематикою займалися зарубіжні автори, а саме Дж. Глаубер [15], Дж Грабер [16], Г. Карпентер, О. Лобанова, О. Махул [14], Ф. Найта, К. Редхеда, М. Чекулаєва, Д. Штайхоффа та інші. При цьому, питання розвитку галузі страхування сільського господарства в Україні потребують подальшого дослідження, особливо в частині адаптації ефективних практик агрострахування провідних країн світу у діяльність вітчизняних аграрних підприємств.

Формулювання цілей дослідження. Метою дослідження є оцінка та узагальнення діючих систем та форм агрострахування в розвинутих країнах світу, а також виокремлення можливих перспектив адаптації зарубіжного досвіду у вітчизняну практику.

Виклад основних результатів та їх обгрунтування. Страхування сільського господарства заро- 
дилося в Європі близько 200 років тому як один зі способів захисту від фінансових втрат. Втрати в сільському господарстві можуть настати від загибелі поголів'я тварин в результаті епідемій захворювань, нещасних випадків тощо. Також від пошкодження посівів сільськогосподарських культур, які спричинені природними катаклізмами (град, посуха, повінь, пилові бурі тощо).

Усю сукупність ризиків, які виникають у сільському господарстві, можна розділити на п'ять груп [1]:

1) Природні ризики (природно-ерозійні процеси) - негативний вплив на отримання сільськогосподарської продукції внаслідок несприятливих погодних умов.

2) Техногенні ризики (фізичне та хімічне забруднення грунтів, використання мінеральних добрив та пестицидів не за нормами, забруднення грунту отрутохімікатами, паливно-мастильними матеріалами, перезволоження та вітрова засоленість земель і підвищення виробничих енерговитрат) - негативно впливають на якість грунтів та знижує врожайність екологічно чистої сільськогосподарської продукції.

3) Антропогенні ризики (водна та вітрова ерозія, погіршення структури грунтів, механічне руйнування та ущільнення грунту, постійне збіднення на гумус і поживні речовини) - впливають на якість грунтів, спричиняють втрату грунтового покриття, зменшують поживні речовини у грунті та порушують природний баланс.

4) Радіаційні ризики (іонізуюче випромінювання радіаційних матеріалів у навколишньому середовищі) - спричиняють розповсюдження радіоактивних матеріалів на сільськогосподарську продукцію, що веде до зниження іï якості або робить їі непридатною для використання.

5) Еколого-економічні ризики (використання екологонебезпечних технологій у процесі виробництва продукції сільського господарства) - несуть негативний вплив на якість та конкурентоспроможність сільськогосподарської продукції.

Агрострахування інтенсивно розвивається на протязі останніх 70-ти років завдяки політиці в розвинених країнах світу, де уряд вбачає у цій сфері страхування важливий інструмент забезпечення продовольчої безпеки держави та зменшення можливих витрат 3 державного бюджету через несприятливі природні умови та інфекційні хвороби тварин. Розвиток агрострахування стимулювали наданням субсидій від держави, які були покликані покрити частину страхових платежів, та створенням державних агентств 3 управління ризиками в сільському господарстві. Створені агентства здійснювали різні функції, зокрема, розробку, стандартизацію, модифікацію, оновлення програм страхування ризиків, визначення їх справедливої вартості, контроль за якістю роботи страхових компаній тощо. Першими стали США, які 1938-го розробили й запровадили федеральну систему підтримки та розвитку страхування аграрної галузі, яка донині залишається найбільш потужної й розвинутою в світі.
Досвід зарубіжних країн в сфері агрострахування свідчить про функціонування в більшості країн національних систем страхування сільськогосподарських ризиків. При цьому кожна держава створює власну, зручну для неї систему страхового захисту аграріїв (рис. 1)[2, 5, 8].

Класичним прикладом сьогодення є система страхування Сполучених Штатів Америки. В США для здійснення державної політики у сфері агрострахування при Міністерстві сільського господарства було засновано Агентство 3 управління ризиками (Risk Management Agency, RMA). Основними напрямами роботи даного Агентства є здійснення контролю за діяльністю страхових компаній, які беруть участь у реалізації державних програм, а також за виконанням страхових угод та розподілом субсидій за страховими договорами [2]. Крім цього, Агентство здійснює керівництво Федеральною корпорацією по страхуванню врожаю FCIC, яка є державною компанією. Корпорація наглядає за діяльністю сільгоспвиробників та страхових агентів, перевіряє ефективність діючих федеральних програм зі страхування врожаїв, надає типові угоди з перестрахування ризиків, а також реалізує програми державної підтримки в сфері аграрної галузі [3].

Американські аграрії мають змогу в рамках федеральної програми страхуватися не лише проти погодних ризиків, а й від можливого зменшення ціни на продукцію галузі сільського господарства, зниження доходу господарств. Дана програма значно розширює їх можливості при виборі страхового продукту, здатного максимально забезпечити бізнесовий інтерес.

До головних державних програм зі страхування врожаїв та доходу і США відносять: Програма захисту від катастрофічних ризиків (Catastrophic Risk Protection, CRP), Програма мультиризикового страхування врожаю (Multiple Peril Crop Insurance, MPCI), Програма «Груповий план» (Group Risk Plan, GRP), Програма захисту доходу (Income Protection, IP) та інші [4].

$\begin{array}{ccc}\text { У Канаді програма страхування сфери сіль- } \\ \text { ського } & \text { господарства } & \text { функціонує }\end{array}$ ше.Федеральним урядом погоджує свої програми 3 кожною провінцією, які пропонують фермерам страхові продукти через Королівські корпорації, які $\epsilon$ комерційними й засновані державою. Кожна провінція здійснює управління страховими програмами самостійно. Звернення з проханням про допомогу до федерального правління відбувається тільки в крайніх випадках. Міжнародні агенти з перестрахування та перестрахувальні брокери здійснюють свою діяльність після офіційного оформлення угод про відносини між приватними страховими компаніями, Королівськими корпораціями та державними органами, які займаються питаннями агрострахування. Прикладами Королівських корпорацій є Програма страхування культур на випадок повної або часткової загибелі врожаю (CIP), Програма страхування виробленої продукції, що призначена для реалізації на ринку (RIP), Національна тристороння стабіліза- 
ційна програма (NTSP), Програма стабілізації доходів виробників (CAIS), Страхування виробництва (PI) та інші. Не зважаючи на те, що мультиризикове страхування перестраховується державою, страхові агенти утримують вагому кількість страхових про- дуктів під своїм контролем, розширяючи їх страхування від граду та деяких інших видів ризиків. Страховики самостійно перестраховують певну кількість чи всі прийняті ризики на зарубіжних ринках перестрахування [5].

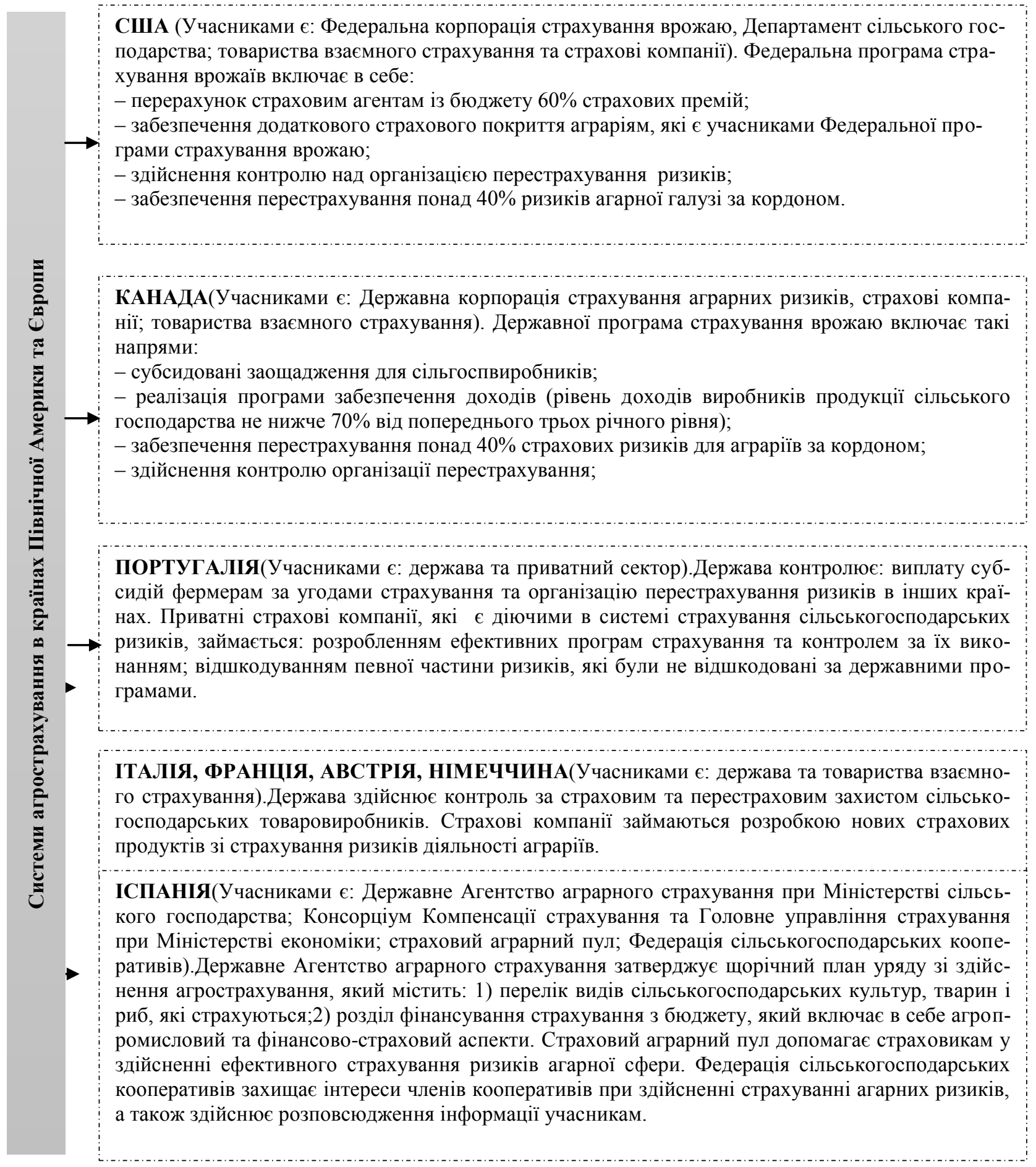

Рис. 1. Діючі системи страхування ризиків сфери сільського господарства у зарубіжних країнах* * узагальнено авторами на основі джерел $[2,5,8]$

3 рисунку видно, що на сьогодні у світі виділяють велику кількість підходи щодо підтримки та розвитку страхування в сільському господарстві, як важливого інструменту для забезпечення розвитку 
виробничого процесу та доходів аграріїв. На сьогодні підтримка страхування агарної сфери в провідних країнах щорічно перевищує 12 млрд дол. (США, Канада, Японія, країни (С) та понад 4 млрд дол. у більше 30 країн, що розвиваються (країни Азії, Африки та Південної Америки).

Вважається, що агрострахування бере свій початок в Німеччині, де перші страхові поліси почали оформляти ще в 1830-их роках. Оформленням цих полісів займалися переважно невеликі товариства взаємного страхування - об'єднання аграріїв, які утворювали спільний фонд. Страхові поліси могли документувати вже після настання страхового випадку, коли було відомо точний розмір понесених збитків, які необхідно виплатити за рахунок учасників таких об'єднання. 3 розширенням своєї діяльності ці фонди взаємодопомоги фермерів переформувалися в новітні страхові компанії, які здійснювали свою діяльність за принципом: спочатку формування страхового фонду за рахунок платежів учасників, а тоді його безпосереднє використання для відшкодування заподіяних страхових збитків.

На сьогоднішній день у Німеччині переважає приватний сектор в системі страхування аграрної сфери, де взагалі не виплачується ніяких субсидій в агрострахування з бюджету держави. Проте, держава бере безпосередню участь у ефективному розвитку системи сільськогосподарського страхування: здійснення активного управління системою через розробку базових страхових продуктів, введення низки обмежень та встановлення технічних рамок роботи системи. А також в країні функціонують програми ситуативних виплат з бюджету держави при настанні стихійних лих. Дані програми є структурованими, а виплати відбуваються лише за умови отримання дозволу Свропейського Союзу [3].

У Португалії впроваджена ефективно працююча система, що покликана забезпечити тісний зв'язок держави й приватного сектору у сфері агрострахування. Головну роль відіграє держава, здійснюючи субсидіювання страхових премій та перестрахування. У Португалії страхування сільськосподарського сектору здійснюється приватними страховиками, а урядова підтримка включає [6]:

- розробку ефективного страхового законодавства;

- впровадження єдиних стандартних страхових полісів;

- запровадження обов'язкового первинного покриття витрат від таких страхових випадків як град та пожежа;

вним переліком);

- встановлення групованого покриття (за пе-

- прийняття нормативних тарифів для розрахунку сум дотацій та премій;

- державні компенсації на певну частину страхових премій;

- державне перестрахування.

Система агрострахування в Іспанії базується на зацікавленості і, відповідно, взаємодії трьох основних учасників - сільськогосподарських виробників, страхових компаній та уряду.
У Центральній та Східній Європі страхування сільського господарства залишається слабо розвиненим. Але, у Польщі агрострахування зазнало найбільшого розвитку. Польські страхові компанії застосовують найновіші фінансові технології, сучасний менеджмент i маркетинг. За діючим законодавством країни підпадають обов'язковому особистому соціальному страхуванню у касі громадського агрострахування. За ігнорування обов'язкового страхування польський сільгоспвиробник сплачує встановлені урядом суми обов'язкових платежів: за відсутність страхового полісу цивільної відповідальності - 60 злотих, а за страхування будівель та споруд - 400 злотих. Обов'язковому страхуванню підлягають будівлі та споруди, які входять до складу аграрного підприємства. Предметом страхування є врожай сільськогосподарських культур, багаторічні насадження, що плодоносять і молоді насадження [2, 7].

Останнім часом страховий ринок Латвії подолав кілька природних етапів розвитку. Страхові компанії розширюють перелік своїх послуг - від класичних базових до унікальних - як у страхуванні, так і в перестрахуванні. В свою чергу, іноземні страховики гарантують надійність та якість пропонованих страхових програм. Страховики $з$ інших країн активно діють на ринку через свої дочірні підприємства, а також великий латвійський капітал. Латвійського страхового ринку жорстко контролюється Комісією 3 ринку фінансів і капіталу Республіки Латвія $[7,12]$.

Загалом, можна виокремити три основні системи агрострахового захисту, що використовуються у зарубіжних країнах [9]:

1. Система катастрофічного покриття передбачає створення державою так званого фонду катастроф, який перестраховується на світових ринках. Ця система діє у Мексиці, Індії, Німеччині.

2. Система державного адміністрування агрострахових програм полягає у створенні спеціального органу, що формує політику агрострахування у країні загалом, створює законодавче забезпечення та координує страхові компанії, які працюють у агростраховій сфері. Ця система характерна для США.

3. Система кооперації держави та страхових компаній полягає у тому, що держава на загальному рівні визначає політику агрострахування, а страхові компанії на місцях, заручившись державною підтримкою, сприяють реалізації програм агрострахування на найбільш вигідних для аграріїв умовах. Ця система запроваджена у більшості країн світу (Туреччині, Icпанії, Португалії, Ізраїлі, Канаді та ін.).

Крім основних вищенаведених систем, існує i такий варіант, як створення державної страхової компанії, що реалізовує агрострахові послуги. Ця система діє у Греції, Білорусі, на Кіпрі. Однак практика ऑii впровадження у цих країнах є неефективною.

В залежності від особливостей агрострахування (історичних, економічних, соціальних особливостей тощо), які притаманні окремим країнам, виділяють такі основні три моделі страхування в секторі сільського господарства (табл. 1). 
Моделі страхування в галузі сільськогосподарського виробництва*

\begin{tabular}{|c|c|c|}
\hline Модель & Країни & Характеристика моделі \\
\hline \multirow[t]{2}{*}{ Американська } & \multirow{2}{*}{$\begin{array}{l}\text { Сполучені Штати } \\
\text { Америки, Канада }\end{array}$} & $\begin{array}{l}\text { Переваги: значна участь уряду у підтримці агрострахування - } \\
\text { надання субсидії на сплату певної долі страхової премії. }\end{array}$ \\
\hline & & Недоліки: високі адміністративні витрати країни. \\
\hline \multirow[t]{2}{*}{ Європейська } & \multirow{2}{*}{$\begin{array}{c}\text { Німеччина, Велика } \\
\text { Британія }\end{array}$} & $\begin{array}{l}\text { Переваги: незначне втручання держави, виробники продукції } \\
\text { сільського господарства купують самостійно страховий поліс } \\
\text { за його повною ціною. }\end{array}$ \\
\hline & & $\begin{array}{l}\text { Недоліки: незахищеність страхувальників та обмеження мож- } \\
\text { ливості розвитку системи. }\end{array}$ \\
\hline Змішана & $\begin{array}{l}\text { Іспанія, Франція, Іта- } \\
\text { лія }\end{array}$ & $\begin{array}{l}\text { Страхування є добровільним процесом, відшкодування від на- } \\
\text { стання ризиків в системі надають приватні страхові компанії } \\
\text { на основі співстрахування. }\end{array}$ \\
\hline
\end{tabular}

* Згруповано автором за даними [9]

Основною відмінною характеристикою американської моделі є велика державна підтримка страхування сільськогосподарських ризиків. Важливим елементом державної підтримки $є$ нарахування субсидії на оплату певної частини страхових премій. Це дасть змогу зменшити вартість страхування для аграріїв та, відповідно, забезпечити масовий характер агрострахування. Свропейську модель можна назвати приватною. Це означає, що держава майже не втручається в процес страхування аграрних ризиків, а також те, що аграрії купують страховий поліс за його повною вартістю. Тому страхові агенти пропонують тільки ті страхові продукти на ринку агростахування, які дійсно можуть бути придбані аграріями по такій ціні. Це в основному продукти страхування лише від окремих видів ризиків, тому що мультиризикові страхові продукти були б для сільгоспвиробників занадто дорогими $[10,11,12]$.

Найбільш ефективним при страхуванні сільськогосподарських ризиків є поєднання цих двох моделей - американської та європейської. В результаті з'являється «змішана» модель. Саме «змішана» модель страхування аграрних ризиків застосовується в Іспанії, яка, за оцінками експертів світового проекту EC Tacis «Вдосконалення управління ризиками фермерських господарств та малих і середніх господарств в аграрному секторі», є державою, що має одну 3 найрозвиненіших системою сільськогосподарського страхування в Європі.

В Іспанії система страхування ризиків сільського господарства характеризується добровільністю страхування, покриття виплат проводиться на основі солідарної відповідальності аграріїв та страхових компаній, держава активно підтримує та розвиває систему агрострахування, всі права та обов'язки сторін чітко визначені й прописані в законодавчих актах і нормах.

При цьому, однією з перспектив застосування міжнародного досвіду з агрострахування до національних реалій $є$ розробка і впровадження найбільш ефективної для українських сільгоспвиробників модель страхування $з$ державною підтримкою, спираючись на досвід Іспанії. Така система має містити в собі адаптований підхід до розрахунку величини страхових субсидій; встановлювати необхідність за- провадження оригінальної страхової перепустки сільгоспвиробників щодо участі у програмах державного сприяння; розробку високоякісні страхові продуктів та послуг, враховуючи також ті умови й чинники, які ведуть до погіршення якості аграрної продукції [13].

Фінансові можливості країн світу є обмеженими, а інші сфери сільськогосподарського сектору теж вимагають державної підтримки й розробки програм, які будуть активно сприяти розвиткові сектору сільського господарства. 3 цієї причини розроблено низку урядових програм страхування аграрних культур, які можуть надавати пряму фінансову підтримку аграріям. А також сприятимуть ефективнішому розплануванню програми фінансової підтримки сільгоспвиробників, що охоплює весь аграрний сектор в довгостроковій перспективі.

Отже, системи страхування ризиків в аграрній сфері різних країн визначаються наступними ключовими аспектами [13]:

- держава має можливість брати безпосередню активну участь у реалізації систем страхування аграрних ризиків;

- поведінка уряду у страхуванні має бути зрозумілою та прозорою для фермерів;

- страхування являється добровільним;

- утворюються професійні державні організації для розробки і впровадження ефективної політики країни у зазначеній сфері;

- уряд держави має надавати страхові субсидії як аграріям, так і страховим компаніям.

Таким чином, зазначимо, що необхідність страхового захисту зумовлена бажанням обмежити матеріальні й нематеріальні збитки, пов'язані з певними ризиками. Нині страхування є один з найбільш значущих секторів економіки для будь-якої країни, оскільки завдяки страхуванню знижується тиск на видаткову частину бюджету щодо відшкодування збитків [14]. В більшості країн страхування сільськогосподарських ризиків базується на організації моделей гарантійного захисту та підтримки з боку держави сільськогосподарських підприємств від збитків, які можуть настати за тих чи інших природнокліматичних умов. Практика діяльності цих країн в сфері агрострахування показує, що основною метою участі уряду держави в менеджменті сільськогоспо- 
дарського страхування являється зменшення, мінімізація та, по можливості, уникнення негативного впливу ризиків, які можуть чекати на фермерів під час здійснення їх діяльності, та часткове погашення страхових премій, а інколи і відшкодування в разі настання певної страхової події.

Висновки та перспективи подальших досліджень. Аналіз досвіду страхування ризиків в сільському господарстві в зарубіжних країнах показує, що на всіх досліджених ринках агрострахування уряд держав виступає партнером для страхових компаній та здійснює фінансові вливання, через субсидування страхових премій та у деяких випадках - покриває деяку частину страхових виплат.

Аналізуючи досвід провідних країн світу, виділяють дві основні моделі страхування аграрних ризиків: американська та європейська. Ці страхові моделі сформовані за специфікою страхових ринків в кожній з країн. Проте, страхування сільського господарства в Іспанії функціонує за змішаною моделлю, застосовуючи методи як і з американської, так і європейської моделей. Проаналізувавши практику страху- вання аграрних ризиків в зарубіжних країнах, для України можна запропонувати такі основні позиції: застосування приватно-державного партнерства, яке застосовується в європейській моделі, з мінімальним рівнем державного втручання; створення експертного центру, що дозволить розвивати і розширювати масштаби агрострахування; створення централізованої бази даних сільськогосподарської та погодної статистики, забезпечити іiі доступність для фахівців; забезпечення рівні 40\% перестрахування агроризиків 3 боку іноземних страхових компаній, що притаманна американській моделі (США, Канада) та ін.

Методи, які ефективно діють в цих країнах, необхідно застосовувати на страховому ринку України. Застосування цих практик дасть змогу розвивати сільське господарство та створити умови для інвестування в агарну галузь.

Таким чином, в ході вивчення зарубіжного ринку страхування сільського господарства було виявлено, що у більшості країн участь держави застосовується у вигляді надання підтримки сільськогосподарським товаровиробникам за агрострахуванням.

\section{Література}

1. Ярмоленко В.В. Вплив факторів на функціонування ринку агрострахування // Бізнес Інформ. № 9.

2019. C. 144-151. doi: 10.32983/2222-4459-2019-9-144-151

2. Кравчук О. В. Становлення аграрного страхування: світовий та вітчизняний досвід // Вісник Сумського національного аграрного університету. Сер. «Фінанси і кредит». 2011. № 2. С. 85-91.

3. Портал про страхування сільськогосподарських ризиків: [інтернет-портал]. URL: http://www.agroinsurance.com/ru/ (дата звернення: 05.02.2020)

4. Минкіна Г.І. Страхування як елемент управління ризиками підприемств АПК // Фінансовий ринок України. 2010. № 3. С. 4 - 11.

5. Тарельник Н. В. Зарубіжний досвід страхування ризиків в аграрній сфері // Ефективна економіка № 6, 2013. URL: http://www.economy.nayka.com.ua/?op=1\&z=2096 (дата звернення: 05.02.2020.)

6. Александрова М.М. Закордонний досвід формування та розвитку систем страхування сільськогосподарських культур: між народ. зб. наук. праць. № 2(20). 2011. С. 26-37.

7. Панченко О., Шоломій А. Розвиток агрострахування в Україні: проблеми та перспективи // Проблеми і перспективи економіки та управління. 2017. № 1 (9). С. 118-126. doi: 10.15673/fie.v9i4.744

8. Танклевська Н.С. Зарубіжний досвід фінансово-кредитного забезпечення розвитку агарних підприємств // Вісник Агарної науки Причорномор'я. Вип. 1 (44). 2008 р. С. 81-87

9. Прокопчук О.Т., Улянич Ю.В., Бечко В. П. Особливості страхування аграрних ризиків у країнах світу // Актуальні проблеми економіки. №3(153). 2014. с.46-53.

10. Федорович I. Зарубіжний досвід страхування ризиків в аграрній сфері. URL: URL: http://dspace.tneu.edu.ua/bitstream/316497/20319/1/18-23.pdf (дата звернення: 05.02.2020).

11. Фисун I. Зарубіжний досвід страхування аграрних ризиків та доцільність його застосування в Україні. URL: http://www.rusnauka.com/1_NIO_2011/Economics/78211.doc.htm (дата звернення: 04.02.2020).

12. Танклевська Н. С., В. В. Ярмоленко Тенденції розвитку страхування сільськогосподарських культур в Україні // Науковий вісник Ужгородського університету. Сер. «Економіка». 2018. Вип.1(51). 381-386. doi: 10.24144/2409-6857.2018.1(51).381-386

13.Третяк К. В. Агрострахування: зарубіжний досвід та ресурси щодо його імплементації в українську страхову практику // Ефективна економіка. 2019. № 1. URL: http://www.economy.nayka.com.ua/?op=1\&z=6828. doi: 10.32702/2307-2105-2019.1.32 (дата звернення: 04.02.2020).

14. Танклевська Н. С., Ярмоленко В.В Методичні підходи до визначення сутності та класифікації страхування // Agriculturaland Resource Economics: International Scientific E-Journal. 2017. Vol. 3. No. 4.147-159.

15. Mahu, O. and Stutley C.J. 2010. Government Supportto Agricultural Insurance: Challengesand Options for Developing Countries. TheWorld Bank. Washington, DC. doi: http://dx.doi.org/10.1596/978-0-8213-8217-2 .

16. Glauber J.W. AgriculturalInsuranceandtheWorldTradeOrganization // IFPRI, Discussion PAPER 01473. 2015. 40 p. URL: http://ebrary.ifpri.org/utils/getfile/collection/p15738coll2/id/129733/filename/129944.pdf. ((retrieved: 05.02.2020). 
17. Graber J. A dipintonewer P\&C opportunities // 18th International Investors'Day, Frankfurt, 14 October 2015. P. 18-23.

18. Keeps America Growing: Crop Insurance Acreage Sets New Markin 2017. February 6, 2018. URL: https://cropinsuranceinamerica.org/crop-insurance-acreage-sets-new-mark-2017/. (retrieved: 05.02.2020).

Стаття надійшла 10.02.2020

Стаття прийнята до друку 24.02.2020

Доступно в мережі Internet 31.03.20

Танклевская Н.С.

доктор экономических наук, профессор

кафедра экономики и финансов

E-mail: ntanklevska@gmail.com

ORCID ID: 0000-0003-2906-4051

Ярмоленко В.В.

аспирант

кафедра экономики и финансов

Херсонский государственный аграрный университет

ул. Стритенская, 23, г. Херсон, Украина, 73006

E-mail: vitalina.yarmolenko2016@gmail.com

ORCID ID: 0000-0001-7567-0082

\section{ПЕРСПЕКТИВЫ АДАПТАЦИИ ЗАРУБЕЖНОГО ОПЫТА АГРОСТРАХОВАНИЯ В УКРАИНЕ}

В статье рассмотрен зарубежный опыт в области страхования рисков аграрной сферы. Было исследовано системы страхования аграрных рисков в различных странах и их характерные особенности. Изучена история развития страхования аграриев и современных действующих участников на рынке страховых услуг. Проанализированы страховые системы Соединенных Штатов Америки и Канады. Также были систематизированы действующие модели агрострахования. Освещены преимущества и недостатки представленных мировых моделей агрострахования. Анализируя опыт ведущих стран мира, было выделено две основные модели страхования аграрных рисков: американская и европейская. Основной отличительной характеристикой американской модели является большая государственная поддержка страхования сельскохозяйственных рисков. Важным элементом государственной поддержки является начисление субсидии на оплату определенной части страховых премий. Это позволит снизить стоимость страхования для аграриев и, соответственно, обеспечить массовый характер агрострахования. Европейскую модель можно назвать частной. Это означает, что государство почти не вмешивается в процесс страхования аграрных рисков, а также то, что аграрии покупают страховой полис по его полной стоимости. Страхование сельского хозяйства в Испании функционирует по смешанной моделью, применяя методы как и с американской, так и европейской моделей. Было предложено применение возможных эффективных направлений страхования с государственной финансовой поддержкой в сфере сельского хозяйства в разрезе главных моделей рынка страховых услуг. Для Украины можно предложить следующие основные позиции: применение частногосударственного партнерства, которое применяется в европейской модели, с минимальным уровнем государственного вмешательства создание экспертного центра, что позволит развивать и расширять масштабы агрострахования; создание централизованной базы данных сельскохозяйственной и погодной статистики, обеспечить его доступность для специалистов; обеспечение уровне 40\% перестрахования агрорисков со стороны иностранных страховых компаний, присущая американской модели (США, Канада) и др. Доказано, что большинство стран мира делают акцент на важность страхования рисков сельскохозяйственного производства как незаменимого финансово-экономического рычага развития сельского хозяйства и экономики страны.

Ключевые слова: риск, агрострахование, системы агрострахования, модели агрострахования, страховые продукты. 


\author{
Tanklevs'ka N. \\ Doctor of Economics, Professor \\ Department of Economics and Finance \\ Yarmolenko V. \\ Postgraduate student \\ Department of Economics and Finance \\ Kherson State Agrarian University \\ st. Stritenskaya, 23, Kherson, Ukraine, 73006 \\ E-mail: vitalina.yarmolenko2016@gmail.com \\ ORCID ID: 0000-0001-7567-0082
}

\title{
PROSPECTS FOR ADAPTING FOREIGN EXPERIENCE IN AGRICULTURAL INSURANCE IN UKRAINE
}

The article discusses foreign experience in the field of agricultural risk insurance. The insurance systems of agricultural risks in various countries and their characteristic features were investigated. The history of the development of insurance of farmers and current active participants in the insurance market has been studied. The insurance systems of the United States of America and Canada have been analyzed. The current agricultural insurance models were also systematized. The advantages and disadvantages of the presented world models of agricultural insurance have been highlighted. Analyzing the experience of the leading countries of the world, two main models of agricultural risk insurance were identified: American and European. The main distinguishing feature of the American model is the large state support for agricultural risk insurance. An important element of state support is the accrual of a subsidy to pay a certain part of insurance premiums. This will reduce the cost of insurance for farmers and, accordingly, ensure the massive nature of agricultural insurance. The European model can be called private. This means that the state almost does not intervene in the process of insurance of agricultural risks, as well as the fact that farmers buy an insurance policy at its full cost. Agricultural insurance in Spain operates according to a mixed model, applying methods with both the American and European models. The use of possible effective directions of insurance with state financial support in the field of agriculture was proposed in the context of the main models of the insurance services market. The following main positions can be proposed for Ukraine: the use of publicprivate partnerships, which are used in the European model, with the minimum level of state intervention, the creation of an expert center that will allow develop and expand the scale of agricultural insurance; creation of a centralized database of agricultural and weather statistics, to ensure its availability for specialists; ensuring the level of $40 \%$ reinsurance of agricultural risks by foreign insurance companies, inherent in the American model (USA, Canada) and others. It has been proved that most countries of the world emphasize the importance of agricultural production risk insurance as an indispensable financial and economic lever for the development of agriculture and the country's economy.

Key words: risk, agricultural insurance, systems of agricultural insurance, models of agricultural insurance, insurance products.

\section{References}

1. Yarmolenko, V. V. (2019). Vplyv faktoriv na funktsionuvannia rynku ahrostrakhuvannia. Biznes Inform, (9), 144-151. doi: 10.32983/2222-4459-2019-9-144-151

2. Kravchuk, O. V. (2011). Stanovlennia ahrarnoho strakhuvannia: svitovyi ta vitchyznianyi dosvid. Visnyk Sumskoho Natsionalnoho Ahrarnoho Universytetu, (2), 85-91.

3. Portal pro strakhuvannia silskohospodarskykh ryzykiv. (2020). Retrieved February 5, 2020, from http://www.agroinsurance.com/ru/

4. Mynkina, H. I. (2010). Strakhuvannia yak element upravlinnia ryzykamy pidpryiemstv APK. Finansovyi Rynok Ukrainy, (3), 04-11.

5. Tarelnyk, N. V. (2013). Zarubizhnyi dosvid strakhuvannia ryzykiv v ahrarnii sferi. Efektyvna Ekonomika, (6). Retrieved February 5, 2020, from http://www.economy.nayka.com.ua/?op=1\&z=2096

6. Aleksandrova, M. M. (2011). Zakordonnyi dosvid formuvannia ta rozvytku system strakhuvannia silskohospodarskykh kultur. Mizh Narod. Zb. Nauk. Prats., (2(20), 26-37.

7. Panchenko, O., \& Sholomii, A. (2017). Rozvytok ahrostrakhuvannia v Ukraini: problemy ta perspektyvy. Problemy i Perspektyvy Ekonomiky Ta Upravlinnia, (1 (9), 118-126. doi: 10.15673/fie.v9i4.744

8. Tanklevska, N. S. (2008). Zarubizhnyi dosvid finansovo-kredytnoho zabezpechennia rozvytku aharnykh pidpryiemstv. Visnyk Aharnoi Nauky Prychornomor'Ia, (1 (44), 81-87. 
9. Prokopchuk, O. T., Ulianych, Yu. V., \& Bechko, V. P. (2014). Osoblyvosti strakhuvannia ahrarnykh ryzykiv u krainakh svitu. Aktualni Problemy Ekonomiky, (3 (153), 46-53.

10. Fedorovych, I. Zarubizhnyi dosvid strakhuvannia ryzykiv v ahrarnii sferi. Retrieved February 5, 2020, from http://dspace.tneu.edu.ua/bitstream/316497/20319/1/18-23.pdf

11. Fysun, I. Zarubizhnyi dosvid strakhuvannia ahrarnykh ryzykiv ta dotsilnist yoho zastosuvannia v Ukraini. Retrieved February 4, 2020, from http://www.rusnauka.com/1_NIO_2011/Economics/78211.doc.htm

12. Tanklevska, N. S., \& Yarmolenko, V. V. (2018). Tendentsii rozvytku strakhuvannia silskohospodarskykh kultur v Ukraini. Naukovyi Visnyk Uzhhorodskoho Universytetu, (1 (51), 381-386. doi: 10.24144/24096857.2018.1(51).381-386

13. Tretiak, K. V. (2019). Ahrostrakhuvannia: zarubizhnyi dosvid ta resursy shchodo yoho implementatsii v ukrainsku strakhovu praktyku. Efektyvna Ekonomika, (1). doi: 10.32702/2307-2105-2019.1.32

14. Tanklevska, N. S., \& Yarmolenko, V. V. (2017). Metodychni pidkhody do vyznachennia sutnosti ta klasyfikatsii strakhuvannia. Agriculturaland Resource Economics, 3(4), 147-159.

15. Mahul, O., \& Stutley, C. J. (2010). Government Supportto Agricultural Insurance: Challengesand Options for Developing Countries. Washington, DC: TheWorld Bank. doi: 10.1596/978-0-8213-8217-2

$\begin{array}{ccc}16 . \text { Glauber, J. W. (2015). Agricultural Insuran ceand the World Trade Organization (pp. 01-40). IFPRI. Re- } \\ \text { trieved } & \text { February } & \text { from }\end{array}$ http://ebrary.ifpri.org/utils/getfile/collection/p15738coll2/id/129733/filename/129944.pdf

17. 18th International Investors'Day. (2015, October 14). A dipintonewer P\&C opportunities. Frankfurt, 18-23.

18. Keeps America Growing: Crop Insurance Acreage Sets New Markin 2017. (2018, February 6). Retrieved February 5, 2020, from https://cropinsuranceinamerica.org/crop-insurance-acreage-sets-new-mark-2017/

Received 10 February 2020

Approved 24 February 2020

Available in Internet 31.03.20

Цитування згідно ДСТУ 8302:2015

Танклевська Н.С., Ярмоленко В.В. Перспективи адаптації зарубіжного досвіду агрострахування в Україні // Економіка харчової промисловості. 2020. Т.12, вип. 1. С. 55-63. doi: 10.15673/fie.v12i1.1669

Cite as APA style citation

Tanklevs'ka, N., \& Yarmolenko, V. (2020). Prospects for adapting foreign experience in agricultural insurance in Ukraine. Food Industry Economics, 12(1), 55-63. doi: 10.15673/fie.v12i1.1669 